技術論文

\title{
IH クッキングヒータが発する高周波騒音および騒音抑制に関する検討
}

\section{A study on the Noise Suppression in High Frequency Acoustic Noise of IH Cooking Heater}

\author{
米盛 弘信*1 (正員)，丸山 諒*1 (学生員)
}

Hironobu YONEMORI (Mem.), Ryo MARUYAMA (Stu. Mem.)

\begin{abstract}
This paper discusses high frequency acoustic noise generated by an IH cooker. Mechanism of high frequency acoustic noise generation is clarified by the experimental study. Recently, influence of the electromagnetic wave on the human body is worried. The symptoms; user of home electronics appliances feels; are headache and nausea. There is a report that some users who are using IH cooking heater also feel these symptoms. We have discovered that the high frequency acoustic noise, which is generated from an IH cooker, indicates strong-level sound pressure. High frequency strong acoustic noise must not be ignored, because its danger on our health is reported scientifically and medical standpoints. Then, it becomes necessary to examine the suppressing method of high frequency acoustic noise. In this paper, generating mechanism of the high frequency $(20 \mathrm{kHz} \sim)$ acoustic noise is made clarify by the experiments. Further, we have experimentally cleared that the lid of a pan has important effect on the suppression of the high frequency acoustic noise.
\end{abstract}

Keywords: IH cooking heater, noise suppression, high frequency acoustic noise, lid of pan, vibration of pan.

\section{1 はじめに}

近年，身近な家庭内等で，電気を用いて高効率加熱 が可能な IH（Induction Heating）クッキングヒータ（以 下, IH 調理器) の需要が増加している。IH 調理器は, 直火を使用せず調理が可能であるため安全性が高い。 しかし, 便利で気軽に使用可能な調理器具である反面, $\mathrm{IH}$ 調理器の使用中に頭痛や吐き気や気分が悪くなる 等の症状が多数報告されている[1]。この症状の主要因 として, IH 調理器から出る電磁波が問題視されている。 しかし, IH 調理器の電磁波は他の家電製品に比べて特 別多いわけではない[2]。

先の研究では[3], IH 調理器で誘導加熱する際に, IH 調理器から高い音圧レベルの高周波騒音が発生してい ることを発見し，これが人体に不快感や自覚症状を与 える原因ではないかと仮説を立てた。音響分野の研究 では，高い音圧レベルの超音波（可聴領域外）が人体 に与える影響について, 超音波暴露問題[4]と題して問 題視されている。通常, 人間は可聴領域外の音を認識 できないが，高い音圧レベル（90dB 以上）の高周波騒 音は人間が知覚すると報告されている[5][6]。IH 調理 器の一般的な加熱コイルの駆動周波数は $20 \mathrm{kHz}$ であり, その高次高調波は超音波領域になる。したがって，可 連絡先： 米盛 弘信， $\bar{\top} 194-0215$ 東京都町田市小山ヶ丘 4-6-8, サレジオ工業高等専門学校 機械電子工学科, e-mail: yonemori@salesio-sp.ac.jp

*1 サレジオ高専
聴領域外に高い音圧レベルの高周波騒音が存在するな らば，人体に何らかの影響を及ぼしていると考えられ る。すなわち, IH 調理器の使用中に発症する自覚症状 は超音波暴露問題に該当すると考えられる。

本論文では，鍋を誘導加熱した際に放射される高周 波騷音の諸特性（鍋振動・駆動周波数と高周波騒音） を解明し, 鍋蓋の使用による騒音抑制方法を提案する。 最初の取り組みとして，鍋材質や鍋の大きさによる高 周波騷音への影響，加熱コイルの駆動周波数と高周波 騒音の関係について明らかにする。最終的に，鍋から 放射される高周波騒音の低減法について一提案を行う。

\section{2 鍋振動と高周波騒音の関係}

本章では，誘導加熱中に生じる鍋振動と鍋から放射 される高周波騒音の関係について解明する。鍋を強制 的に振動させた際に放射される高周波騒音の測定と実 際の誘導加熱中に鍋から放射される高周波騒音の測定 を行い，両実験より鍋振動が高周波騒音に与える影響 を解明する。

\section{1 鍋を強制振動させた際に放射される高周波騒音}

\section{1 .1 実験方法}

本実験では，鍋を強制的に振動させた際に，鍋振動が 鍋から放射される高周波騒音に与える影響を解明する。 Fig. 1 に実験構成を示す。なお，無響音室（暗騒音 : 18dB）で行う。 


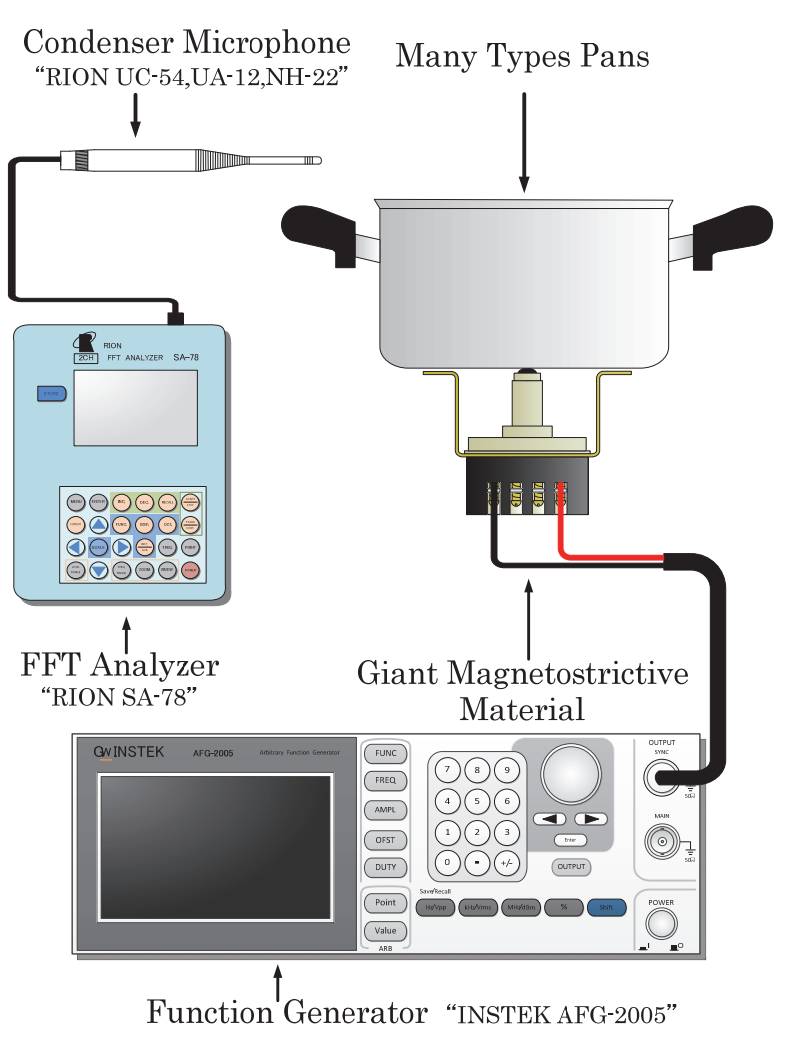

Fig.1 Structure of experimental system.

(1) ファンクションジェネレータに磁歪素子を接続 し，鍋を磁歪素子の上に固定する。

(2) ファンクションジェネレータを $20 \mathrm{kHz}, 5 \mathrm{Vp}-\mathrm{p}$ に 設定し，鍋を強制的に振動させる。

(3) コンデンサマイクロフォンを FFT 分析器に接続 して振動音を測定し，周波数分析を行う。

(4)鍋の種類を変更し, (1)～(3)の実験を行う。

ただし, マイクロフォンまでの距離は, 調理器前面 に立つユーザの耳の位置を考慮して, 鍋の中心から水 平方向 $30 \mathrm{~cm}$ ，垂直方向 $70 \mathrm{~cm}$ とする。

\section{1 .2 実験結果}

Fig. 2 と Fig. 3 に鍋から放射される高周波騒音の周波 数分析結果を示す。今回，5つの異なる鍋底径におい て実験を行ったが，各鍋において同じ傾向であったた め，鍋素材ごとに代表例の結果を述べる。

Fig. 2 より，三層ステンレス鋼鍋を $20 \mathrm{kHz}$ で強制振 動させた場合， $20 \mathrm{kHz}$ 付近に約 $68 \mathrm{~dB}$ のスペクトルが 発生していることがわかる。また，Fig. 3 より，ほう ろう鍋を $20 \mathrm{kHz}$ で強制振動させた場合も三層ステンレ ス鋼鍋と同様に，20kHz 付近に約 $75 \mathrm{~dB}$ のスペクトル

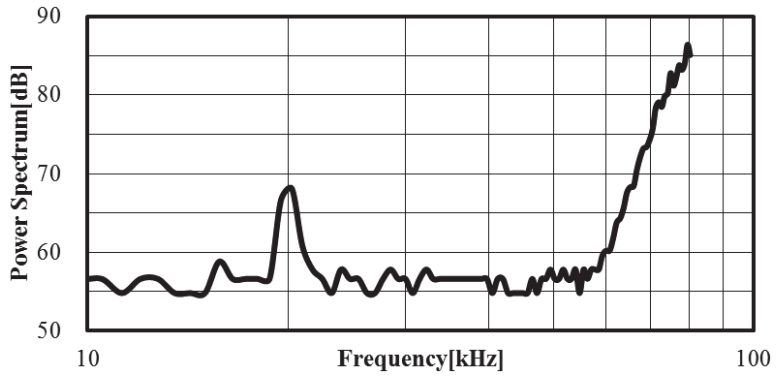

Fig. 2 Vibration acoustic noise of three-layers stainless steel pan. (Diameter : 20cm)

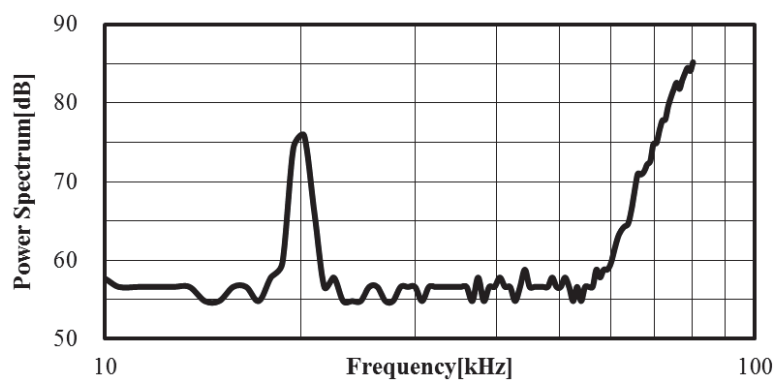

Fig. 3 Vibration acoustic noise of enameled pan.

(Diameter : $18 \mathrm{~cm}$ )

が発生していることがわかる。

これらの結果より，全ての鍋において鍋振動と高周 波騒音のスペクトルが一致していることがわかる。よ って，鍋振動が高周波騒音の要因であるといえる。な お， $60 \mathrm{kHz}$ 付近から利得が上昇しているが，測定器の フロアノイズであり，音ではないことを付記する。

\section{2 誘導加熱中に鍋から放射される高周波騒音}

\section{2 .1 実験方法}

本実験では，誘導加熱中における高周波騷音と鍋振 動の関係を解明する。Fig. 4 に実験構成を示す。なお, 電源等の関係上，無響音室が利用できないため静肃状 態の実験室で行う。

(1) IH 対応鍋に水 $500 \mathrm{cc}$ を入れる。

(2) 出力を調整し, 純音を出す状態で誘導加熱を行う。

(3) コンデンサマイクロフォンを FFT 分析器に接続 して高周波騒音を測定し，周波数分析を行う。

(4) レーザドップラ非接触振動計を用いて鍋の振動 を測定する。使用するモードは速度モードである。

(5) FFT 分析器と振動計の出力をディジタル・オシロ スコープに接続し，時間波形の観察と周波数分析 を行う。

６）鍋の種類を変更し，(1)～(5)の実験を行う。 


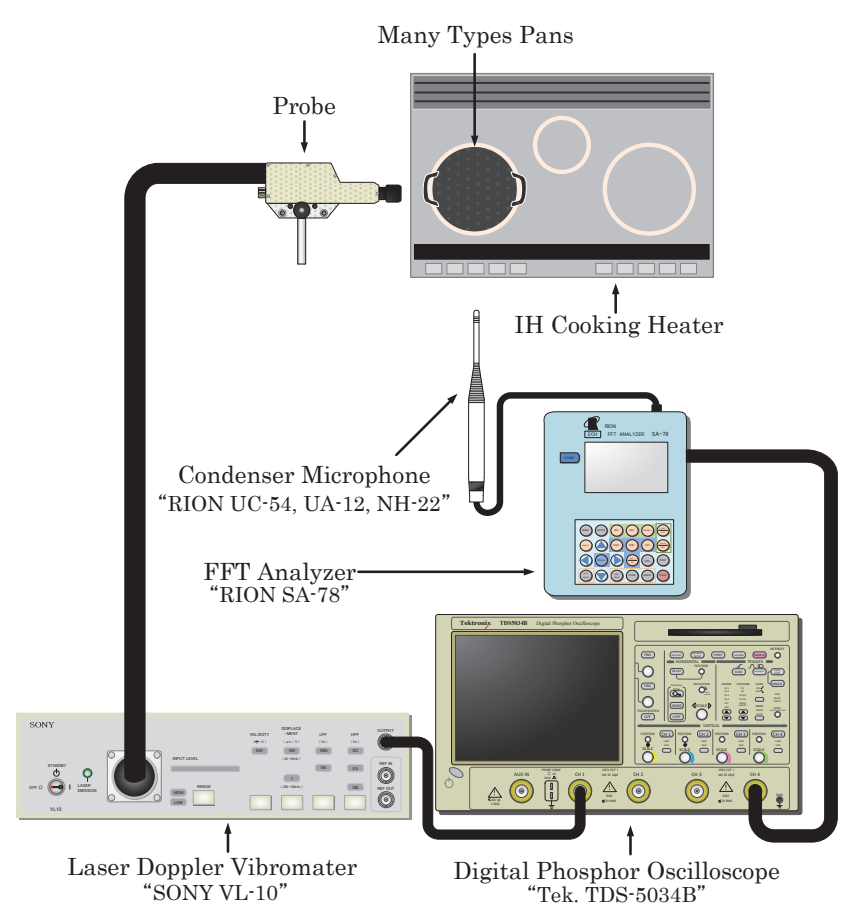

Fig. 4 Structure of experimental system.

ただし，マイクロフォンまでの距離は，調理器前面 に立つユーザの耳の位置を考慮して, 鍋の中心から水 平方向 $30 \mathrm{~cm}$, 垂直方向 $70 \mathrm{~cm}$ とする。また, マイクロ フォンと振動測定用プックアッププローブは IH 調理 器と接触しておらず, 他の振動等の影響が無いように 考慮していることを付記する。

\section{2 .2 実験結果}

Fig. 5 に鍋から放射される高周波騒音と鍋振動の周 波数分析結果を示す。ただし, M1 : 鍋振動の時間波形, M2 : 鍋振動のスペクトル, M3 : 高周波騒音の時間波 形, M4 : 高周波騷音のスペクトルである。また, 各波 形（M1〜M4）の“↔”とスクリーン左端が基準 0 で ある。今回，5 つの異なる鍋底径において実験を行っ たが，各鍋において同じ傾向であったため，代表例と して，鍋底径 $20 \mathrm{~cm}$ (三層ステンレス鋼鍋)，18cm（ほ うろう鍋) の結果を述べる。

Fig. 5 (a)より, 三層ステンレス鋼鍋の鍋振動と高周波 騒音は正弦波状の時間波形であり, 約 $45 \mathrm{kHz}$ 前後に鍋 振動と高周波騒音のスペクトルが発生していることが わかる。Fig. 5 (b)より, ほうろう鍋の鍋振動と高周波 騒音も三層ステンレス鋼鍋と同様, 正弦波状の時間波 形であり, 約 $45 \mathrm{kHz}$ 前後に鍋振動と高周波騒音のスペ クトルが発生していることがわかる。これらの結果よ り，鍋振動と高周波騒音のスペクトルが一致してお

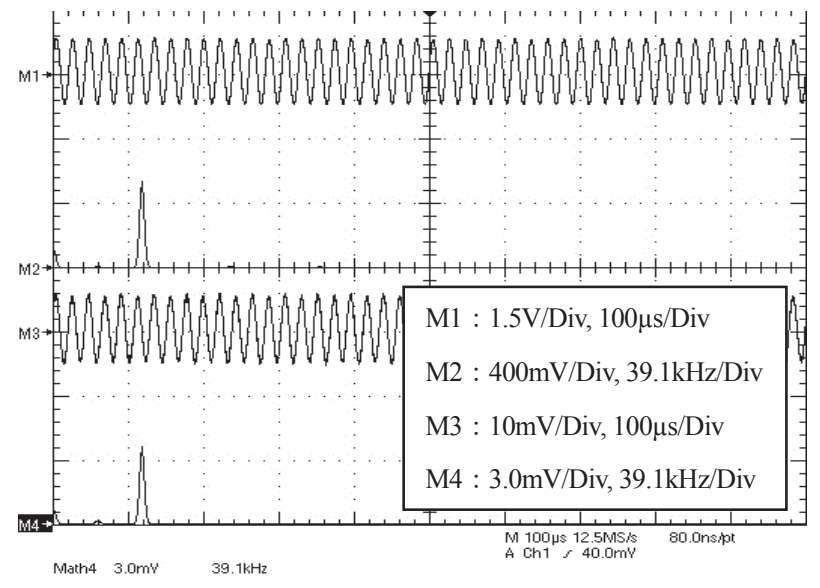

(a) Three-layers stainless steel pan.(Diameter : $20 \mathrm{~cm}$ )

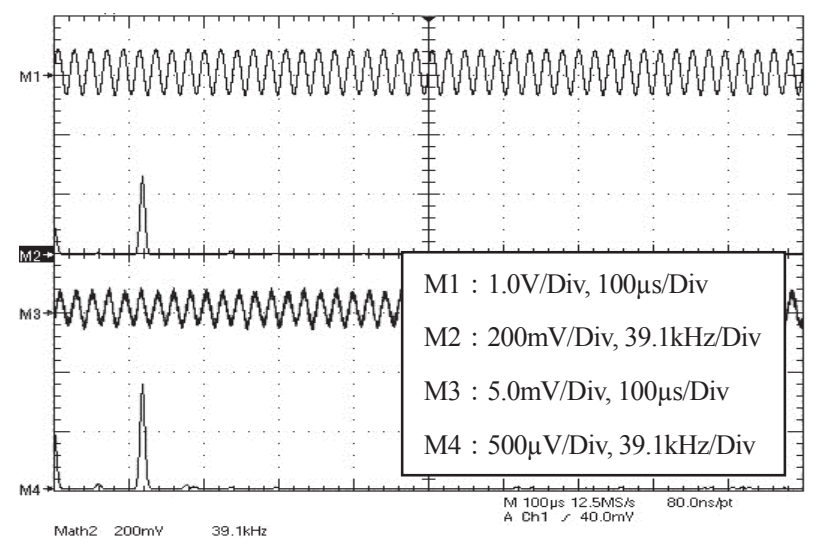

(b) Enameled pan.(Diameter : 18cm)

Fig. 5 Pan vibration and high frequency acoustic noise.

り，鍋振動が高周波騒音の要因であるといえる。

各鍋において高周波騒音のスペクトルが発生して いるが，これは誘導加熱時に流れる加熱コイル電流と 鍋の渦電流による反発力によって鍋が振動し，鍋自体 がスピーカのように音を発していると考えられる。

\section{3 駆動周波数が高周波騒音に与える影響}

本章では，誘導加熱時の加熱コイル電流周波数の周 波数分析結果と高周波騒音の周波数分析結果との比較 を行い，誘導加熱時におけるコイル電流周波数と鍋か ら放射される高周波騷音の関係を解明する。

\section{1 実験方法}

本実験では，誘導加熱時におけるコイル電圧・電流 と鍋から放射される高周波騒音を測定する。Fig. 6 に 実験構成を示す。なお，電源等の関係上，無響音室が 利用できないので静肃状態の実験室で行う。

(1) IH 対応鍋に水 $500 \mathrm{cc}$ を入れる。 


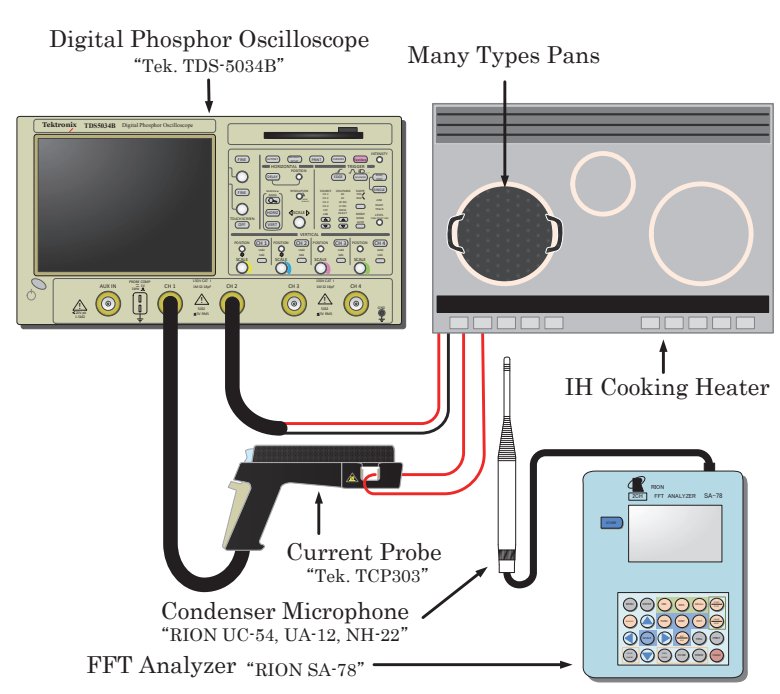

Fig. 6 Structure of experimental system.

(2) 最大出力で誘導加熱を行う。

(3) コンデンサマイクロフォンを FFT 分析器に接続 して高周波騒音を測定し，周波数分析を行う。

(4) ディジタル・オシロスコープに差動プローブを接 続し, 加熱コイルのコイル電圧を測定し, 周波数 分析を行う。

(5) ディジタル・オシロスコープに電流プローブを接 続し, 加熱コイルのコイル電流を測定し, 周波数 分析を行う。

（6) 鍋の種類を変更し， (1)～(5)の実験を行う。

ただし，鍋からマイクロフォンまでの距離は，調理 器前面に立つユーザの耳の位置を考慮して, 鍋中心か ら水平方向 $30 \mathrm{~cm}$, 垂直方向 $70 \mathrm{~cm}$ とする。

\section{2 実験結果}

Fig. 7 (a)に三層ステンレス鋼鍋(鍋底径 20cm), Fig. 8(a) にほうろう鍋 (鍋底径 $18 \mathrm{~cm}$ ) の誘導加熱時に発生する 高周波騒音の周波数分析結果を示す。また, Fig. 7(b) に 三層ステンレス鋼鍋（鍋底径 $20 \mathrm{~cm}$ ), Fig. 8(b)にほう万 う鍋（鍋底径 $18 \mathrm{~cm}$ ）を誘導加熱した際のコイル電圧・ 電流をディジタル・オシロスコープの FFT 機能で周波 数分析した結果を示す。ただし, M1 : コイル電圧のス ペクトル, M2: コイル電流のスペクトルである。また, 各波形（M1〜M2）の “ ‘ とスクリーン左端が基準 0 である。Fig. 7(a)より三層ステンレス鋼鍋の誘導加熱 時には, $23 \mathrm{kHz}$ 付近で約 $80 \mathrm{~dB}$ の高周波騒音の基音が 発生した。また, 基音の約 2 倍である $46 \mathrm{kHz}$ 付近で約 104dB の倍音が発生した。このとき，コイル電流の周 波数分析結果に着目寸ると, Fig. 8 (b)より $23 \mathrm{kHz}$ 付近

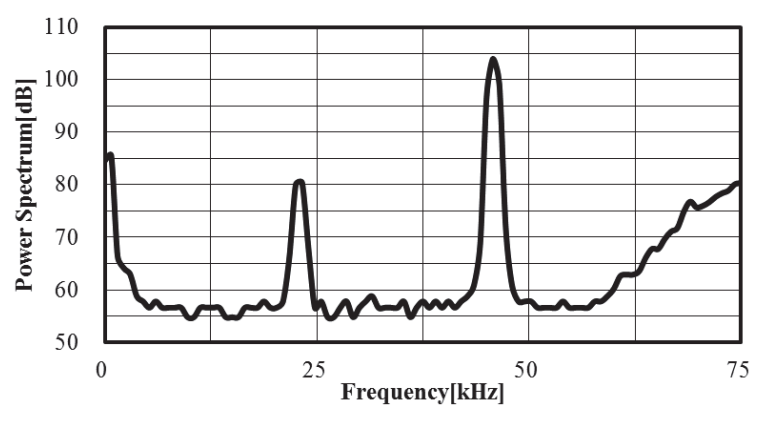

(a) Frequency characteristics of the high frequency acoustic noise.

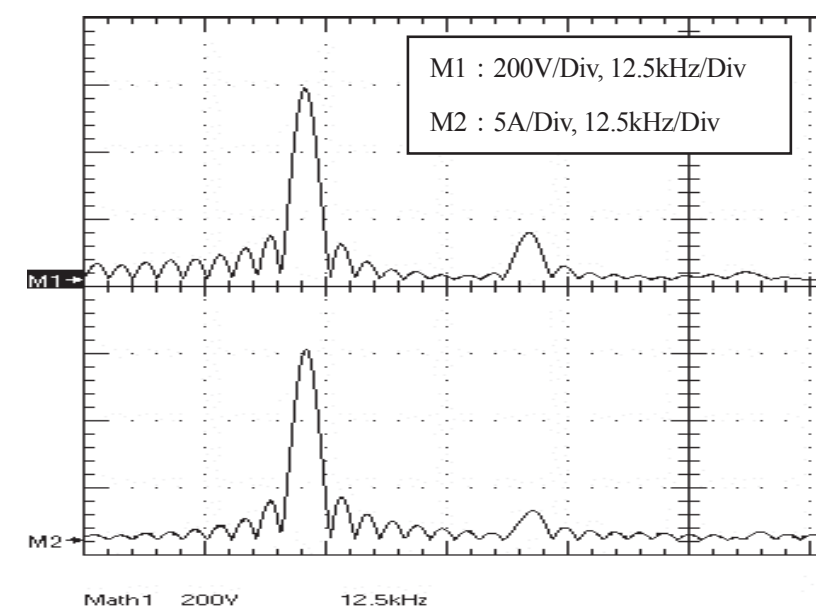

(b) Frequency characteristics of the coil voltage and current.

Fig. 7 Three-layer stainless steel pan : Coil voltage, current and high frequency noise.

で約 14A の電流が流れたことがわかる。また，2 倍周 波数である $46 \mathrm{kHz}$ 付近で約 $2.2 \mathrm{~A}$ の電流が流れたこと がわかる。

Fig. 8 (a)よりほうろう鍋の誘導加熱時には， $23 \mathrm{kHz}$ 付近で約 70dB の高周波騒音の基音が発生した。また, 基音の約 2 倍である $46 \mathrm{kHz}$ 付近で約 $84 \mathrm{~dB}$ の倍音が発 生した。このとき, コイル電流の周波数分析結果に着 目寸ると, Fig. 8 (b)より $23 \mathrm{kHz}$ 付近で約 $16 \mathrm{~A}$ の電流が 流れたことがわかる。また， 2 倍周波数である $46 \mathrm{kHz}$ 付近で約 $4.1 \mathrm{~A}$ の電流が流れたことがわかる。これらの 結果より，誘導加熱時に鍋から放射される高周波騷音 は, コイル電流の周波数と一致していることがわかる。 なお，鍋の高周波騒音の周波数分析結果で $0 \sim 10 \mathrm{kHz}$ 付近の利得が高いが，これは実験環境における雑音で あるため，鍋から放射される高周波騒音でない。さら に, $60 \mathrm{kHz}$ 付近から利得が上昇しているが, 測定器の フロアノイズであり，音ではないことを付記する。 


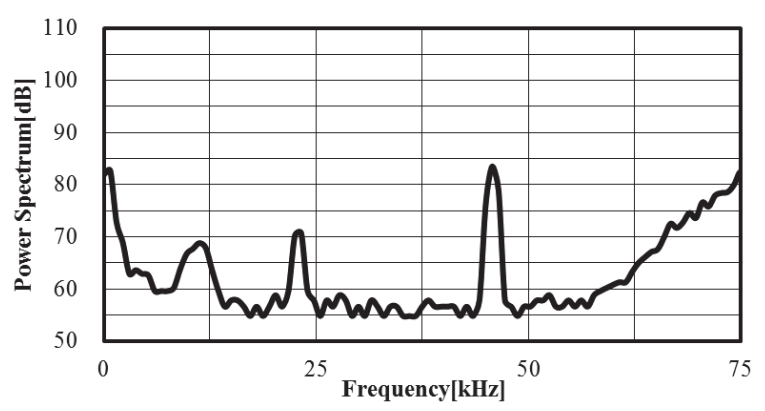

(a) Frequency characteristics of the high frequency acoustic noise.

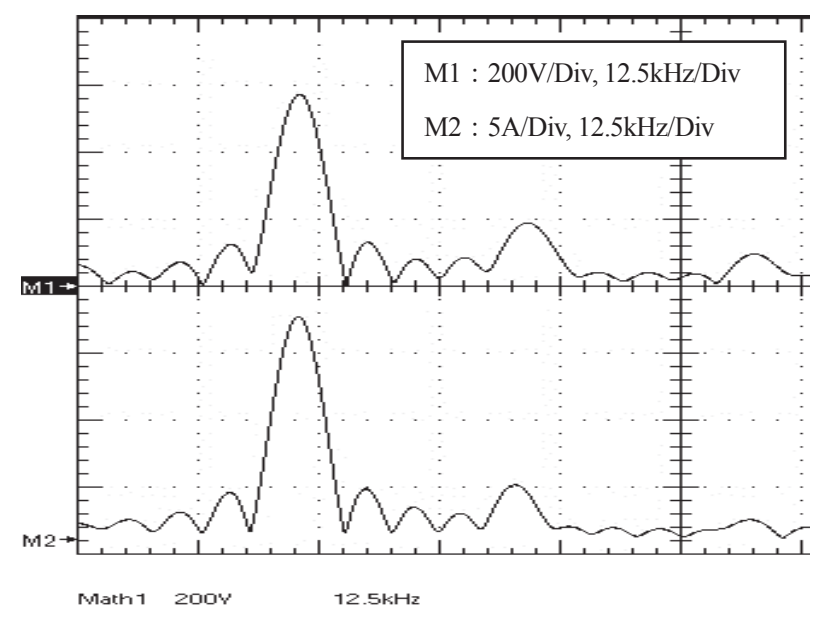

(b) Frequency characteristics of the coil voltage and current.

Fig. 8 Enameled pan : Coil voltage, current and high frequency noise.

\section{4 鍋蓋の有無が高周波騒音に与える影響}

高周波騷音の発生原因は鍋の振動であることから， 鍋蓋を使用することで鍋から放射される高周波騒音を 低減することができると考えられる。本章では, 誘導 加熱時において，鍋蓋を使用・未使用の場合の高周波 騒音を測定し, 鍋蓋の有無が鍋から放射される高周波 騒音に与える影響を解明する。

\section{1 実験方法}

本実験では, 200V オールメタル対応型 IH 調理器を 用いて鍋を誘導加熱した際に放射される高周波騒音を 測定する。実験構成は, Fig. 4 の騒音計測法と同様で ある。なお, 電源等の関係上, 無響音室の利用できな いため静肃状態の実験室で行う。

(1) $\mathrm{IH}$ 対応鍋に水 $500 \mathrm{cc}$ を入れる。

(2) 最大出力で誘導加熱を行う。

(3) コンデンサマイクロフォンを FFT 分析器に接続
して高周波騒音を測定し，周波数分析を行う。

(4)鍋蓋を使用した状態で(1)〜 (3)の実験を行う。

(5)鍋の種類を変更し, (1)〜 (4)の実験を行う。

ただし，鍋からマイクロフォンまでの距離は，調理 器前面に立つユーザの耳の位置を考慮して，鍋中心か ら水平方向 $30 \mathrm{~cm}$, 垂直方向 $70 \mathrm{~cm}$ とする。

\section{2 実験結果}

Fig. 9 (a)(b)，Fig. 10(a)(b)に誘導加熱時に鍋から放射 される高周波騒音の周波数分析結果を示す。Fig. 9(a)(b)に三層ステンレス鋼鍋（鍋底径 : $20 \mathrm{~cm}$ ）から放 射される高周波騒音の鍋蓋の有無に対する比較結果を 示す。Fig. 9(a)より, 鍋蓋が無い状態での誘導加熱時に は， $23 \mathrm{kHz}$ 付近で約 $80 \mathrm{~dB}$ の高周波騒音の基音が発生 した。また, 基音の約 2 倍である $45 \mathrm{kHz}$ 付近で約 $104 \mathrm{~dB}$ の倍音が発生した。Fig.9(b)より, 鍋蓋が有る状態での 誘導加熱時には， $23 \mathrm{kHz}$ 付近で約 $76 \mathrm{~dB}$ の高周波騒音 の基音が発生した。また，基音の約 2 倍である $45 \mathrm{kHz}$ 付近で約 $101 \mathrm{~dB}$ の倍音が発生した。

今回，人体に影響があると報告事例のある $90 \mathrm{~dB}$ 以 上の騒音[5][6]を有する倍音成分について議論する。鍋 蓋がある状態における高周波騒音の倍音成分は，鍋蓋 が無い状態に比へて約 $4 \mathrm{~dB}$ 減少していることが確認で きた。

次に, Fig. 10(a)(b)にほうろう鍋（鍋底径 : 18cm）か ら放射される高周波騒音の鍋蓋の有無に対する比較結 果を示す。Fig. 10 (a)より, 鍋蓋が無い状態での誘導加 熱時には，23kHz 付近で約 $70 \mathrm{~dB}$ の高周波騒音の基音 が発生した。また，基音の約 2 倍である $45 \mathrm{kHz}$ 付近で 約 84dB の倍音が発生した。

Fig. 10 (b)より, 鍋蓋が有る状態での誘導加熱時には, $23 \mathrm{kHz}$ 付近で約 $71 \mathrm{~dB}$ の高周波騒音の基音が発生した。 また，基音の約 2 倍である $45 \mathrm{kHz}$ 付近で約 $81 \mathrm{~dB}$ の倍 音が発生した。こちらも三層ステンレス鋼鍋と同様, 鍋蓋がある状態での高周波騒音の倍音成分は，鍋蓋が 無い状態に比べて約 $3 \mathrm{~dB}$ 減少していることが確認でき た。これらの結果より，鍋から放射される高周波騒音 の倍音は，鍋蓋を使用することにより低減できると考 えられる。しかし, Fig. 10(a)(b)のほうろう鍋の基音と 倍音は可聴領域外の $90 \mathrm{~dB}$ 以下であり，文献[5][6]を考 慮すれば，人体への影響は極小であると考えられる。 なお, 全ての鍋において 60〜 70kHz 付近から音圧レベ ルが上昇しているが，測定器の特性上現れるものであ り，測定值とは無関係であることを付記する。 


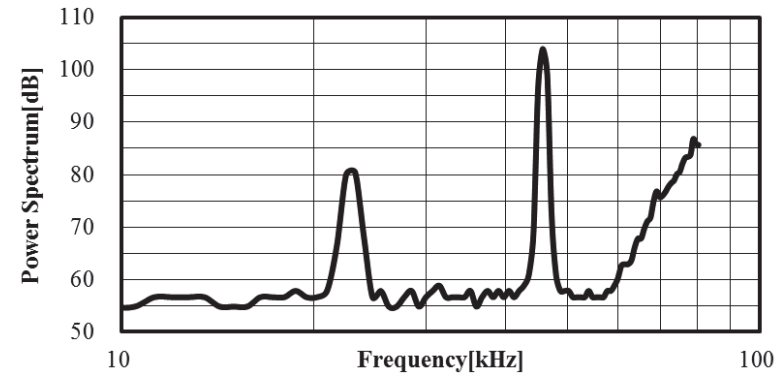

(a) Non-add pan lid

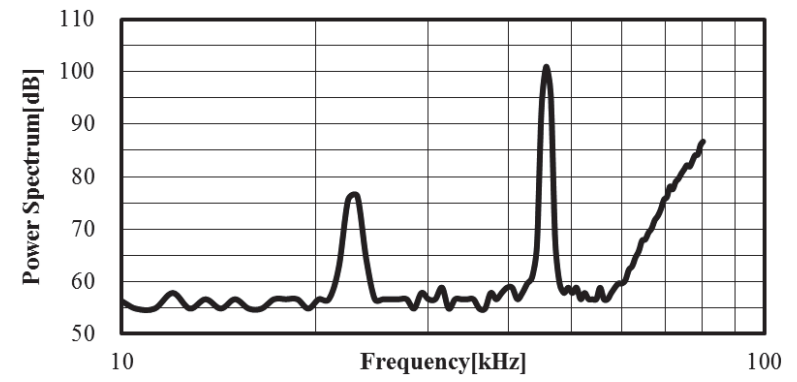

(b) Add pan lid

Fig. 9 High frequency acoustic noise of three-layer stainless steel pan.(Diameter : $20 \mathrm{~cm}$ )

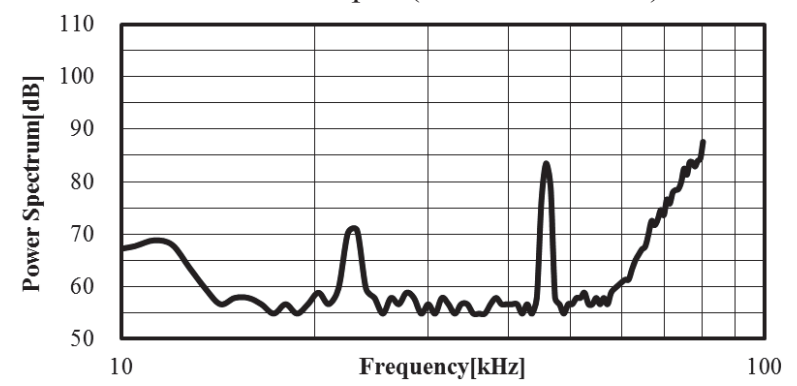

(a) Non-add pan lid

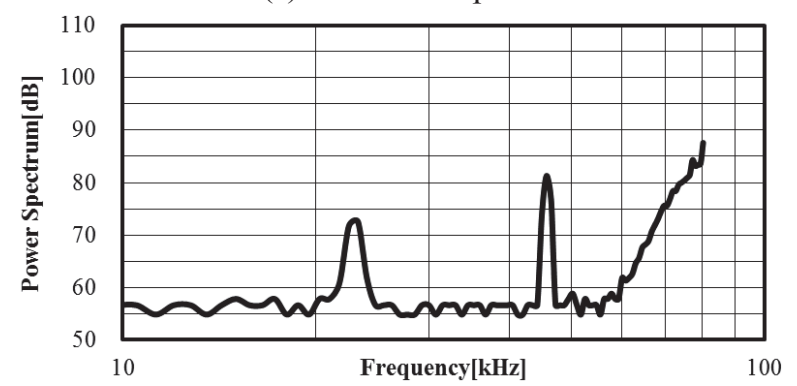

(b) Add pan lid

Fig. 10 High frequency acoustic noise of enameled pan.(Diameter : $18 \mathrm{~cm}$ )

\section{5 まとめ}

本論文では，鍋を誘導加熱した際に放射される高周 波騒音の諸特性を測定し，鍋材質，鍋の大きさによる 高周波騒音への影響や，加熱コイルの駆動周波数と高 周波騒音の関係について解明した。以下に本研究で得 られた成果を示す。

（1）鍋振動と高周波騒音の関係
磁歪素子を用いて鍋を $20 \mathrm{kHz}$ で強制振動させて振動 音を測定したところ， $20 \mathrm{kHz}$ 付近に高周波騒音のスペ クトルが発生していることを確認した。これらの結果 より，鍋振動と高周波騒音のスペクトルが一致してい るため，鍋振動が高周波騒音の要因であることを明ら かにした。

（2）駆動周波数が高周波騒音に与える影響

誘導加熱時の高周波騒音と加熱コイル電圧・電流を 測定したところ，高周波騒音のスペクトルとほぼ同じ 周波数帯に加熱コイル電圧・電流周波数のスペクトル が存在していることを確認した。これらの結果より， 誘導加熱時に鍋から放射される高周波騒音は，コイル 電流の周波数に影響されることを明らかにした。

（3）鍋蓋の有無が高周波騒音に与える影響

誘導加熱時の高周波騒音を測定するにあたって，鍋 蓋の有無の比較実験を行ったところ，鍋蓋がある状態 での高周波騒音の倍音成分は，鍋蓋が無い状態に比べ て約 $4 \mathrm{~dB}$ 前後低減していることが確認できた。これら の結果より，人体への影響が懸念される $90 \mathrm{~dB}$ 以上の 高周波騒音を発するステンレス鋼鍋から放射される高 周波騷音は，鍋蓋を使用することにより低減できるこ とを明らかにした。

以上, 誘導加熱時に IH 調理器から放射される高周 波騒音についての諸特性を明らかにした。さらに，誘 導加熱時に鍋蓋を使用した際に高周波騒音が低減した ことにより，鍋蓋を使用することによる高周波騒音の 一低減法を提案する。今後は，4 章の結果よりも騒音 抑制効果の高い方法を模索して行く予定である。

\section{謝辞}

本研究は, 高専一長岡技科大 共同研究助成によって 行われました。関係各位に感謝致します。

(2014 年 3 月 15 日受付, 2014 年 10 月 20 日再受付, 2014 年 12 月 23 日再々受付)

\section{参考文献}

[1] 眯樋哲夫, IH 調理器と電磁波被害, 三五館, p.4, 2005.

[2] 鈴木浪平, 私立広康, 家庭用 IHクッキングヒータ技術, 三菱電機技報, Vol.80, p.11，2006.

[3] 米盛弘信, 藤原章裕, IH クッキングヒータが発する高 周波騒音の指向性, 第 23 回「電磁力関連のダイナミク ス」シンポジウム講演論文集，pp.437-442， 2011.

[4] 鎌倉友男, 超音波領域における聴覚閾值，日本音響学 会 超音波研究会, pp.5-6, 2007.

[5] 伊藤陽一, 実験室における空中超音波暴露とその影響, 日本音響学会誌， 67 巻 5 号, pp.194-199, 2011.

[6] 蘆原 郁, 高周波聴覚閾值の精神物理学的測定, 日本 音響学会誌, 67 巻 5 号, pp.208-213, 2011. 